\title{
Higher Education Curriculum and the Capability and Functioning of Young People in Nigeria
}

\author{
David O. Akeju \\ Department of Sociology \\ University of Lagos
}

Corresponding Author: davidakeju@gmail.com, dakeju@unilag.edu.ng

\begin{abstract}
The demand for higher education among young people has resulted in the huge number of candidates seeking enrollment into higher institutions of learning in Nigeria. The population has consistently increased without a corresponding expansion in educational infrastructure and adjustment in curriculum. Drawing from Amartya Sen's theory of capabilities and functioning, this paper argues that the population of young people with tertiary education represents a cohort whose capabilities and functioning are at variance with local development needs. The paper further expands the argument by asserting that tertiary educational curriculum, in its current state, is shallow and is a major contributor to the poor state of enrollment for tertiary education and the poor state of youth unemployment in the country. It recommends a re-structuring of the tertiary education system and adjustment to curriculum to meet local industrial demand.
\end{abstract}

Keywords: higher education, curriculum, capabilities, functioning

\section{Background}

Tertiary educational institutions in Nigeria represent one of the many institutions where capabilities and the ability to make choices are expanded. This process begins with enrolment and subsequent training of people to provide human capital for growth and development. While the reality of the problem between enrolment and space has been acknowledged, studies on enrolment into tertiary educational institutions in Nigeria have mainly focused on gender disparity (Odejide, et al., 2006). However, tertiary education enrolment process in Nigeria is fraught with diverse systemic issues that leave a large proportion of young female and male without access to tertiary education (Ajake; Oba; Ekpo 2014). Annually, the figures take up new forms as more young males and females graduate from secondary school level into a pool of in-between-school young adults (Obono and Mohammed, 2010).

Interestingly, the Nigerian socio-economic space places a very high value on certification, and less on capability. This has triggered the demand for certificates as is evident in the steady increase in the number of young people seeking enrolment into Nigerian tertiary institutions. In 2005, an average of 868,000 young people sought for admission into Nigerian universities out of which only 200,000 (23\%) were adjudged to have been successful even though the carrying capacity of Nigerian universities was only 150,000. By 2010, 
some 1,375,671 young people sought for admission into the universities; however, the carrying capacity of universities remained the same (Jamila, 2010). In order to address this problem, more universities were established to the extent that in 2005 there were 51 of such institutions; the number increased, by more than 50 percent in 2013, to 128 (Ademola et al., 2014). Despite the expansion, the growing demand by young people for university education has not been effectively addressed (Aluede et al., 2012; Ajake et. al., 2014).

Similarly, the labour market is replete with unemployed young graduates, majority of who have been deemed unemployable. Nigeria has one of the worst unemployment statistics in Africa with 40 million unemployed and underemployed young people (NISER, 2013; World Bank Statistics, 2009). A cursory look at the unemployment trend since 1985 till date shows that Nigeria was worst hit shortly after the advent of democracy. It rose astronomically between 1988 and 1999 at a time the nation was at the threshold of democratic governance. At the inception of the government of Olusegun Obasanjo, unemployment witnessed a sharp decline from $19.7 \%$ to $12.7 \%$. This sharp decrease in unemployment rates in 1999 underscores the role of democracy in job creation. Although, democracy in Nigeria has been able to provide opportunities and expand alternative options for young people, the magnitude of the problem has drowned this seemingly successful stride. Thus, the trend could not be sustained.

The question to ask is whether unemployed young Nigerian graduates are incapable or that there are no tasks to which their capabilities could be deployed? The curriculum of most Nigerian tertiary educational institutions was largely inherited from the colonial masters, particularly the first and second generation universities. Those of newly established universities are often patterned along those of western universities in a bid to become globally competitive. Thus, local needs have been largely overlooked at the expense of national growth and development. Consequently, the means for developing the capability of young people within tertiary institutions was, and has been, very weak because of the disjuncture between the curriculum and local industrial needs. This type of curriculum system downplays the inherent potential within the Nigerian social, political and economic space for growth and development and thus renders young people incapable of developing their inherent potentials and deploying their capabilities.

Across the world, policy makers are fast realising that high GNP (Gross National Product) growth rates have failed to reduce the socioeconomic deprivation of people in developing countries. It is also becoming more apparent that high income does not necessarily ensure protection against social problems such as prostitution, poverty, drug abuse, homelessness, violence and the breakdown of family institutions. The antidotes to the current social ills and underdevelopment experienced in many African countries and by extension, Nigeria, lie in strategic deployment of available means and resources to expand human capabilities and choices to create opportunities among the vast majority of the people. The capabilities and functioning of people are directly 
determined by the measure of skills possessed, the use to which acquired skills could be deployed, the choices that could be made among many alternatives and the opportunities available (Ajake et al., 2011).

This perspective has two sides: the formation of human capabilities such as improved health, knowledge and skills, and the use people make of their acquired capabilities. The point is; if the scales of human development do not adequately balance the two sides, considerable human frustration may result. The second prong can only be upheld if the first is rightly in place. The scenario playing out in Nigeria reveals that the two sides do not adequately balance. Against the backdrop of a growing pool of in-between-school female and male young adults without enhanced capabilities, Nigeria's quest for growth and development is under serious threat (Babalola, 2007). Within this context therefore, the critical questions are: Why are there huge number of unemployed young people in Nigeria? What are the available and sustainable alternatives that could enhance their capability? What are the long-term approaches to solving this problem? I shall now attempt to answer these questions, but first, it is necessary to briefly examine the work of Amartya Sen (1987) on capability and functioning.

\section{The Theory of Capability and Functioning}

Amartya Sen's theory on capability and functioning has been an influential theoretical perspective of development since the mid-1980s. The argument of this perspective is that in defining good change what really mattered to both the poor and non-poor person was the "capability to function", and that "poverty cannot be properly measured by income or even by utility as conventionally understood; what matters is not the things a person has - or the feelings these provide - but what a person is or can be and does or can do. What matters for well-being is not just the characteristics of commodities consumed, as in the utility approach, but what use the consumer can and does make of commodities.

The essentials of the capability approach focuses directly on the quality of life that individuals are actually able to achieve. This quality of life is analyzed in terms of the core concepts of 'functionings' and 'capability'. While functionings are viewed as the states of 'being and doing' such as having shelter, having a god job, being in school, capability refers to the set of valuable functionings that a person can effectively access. 


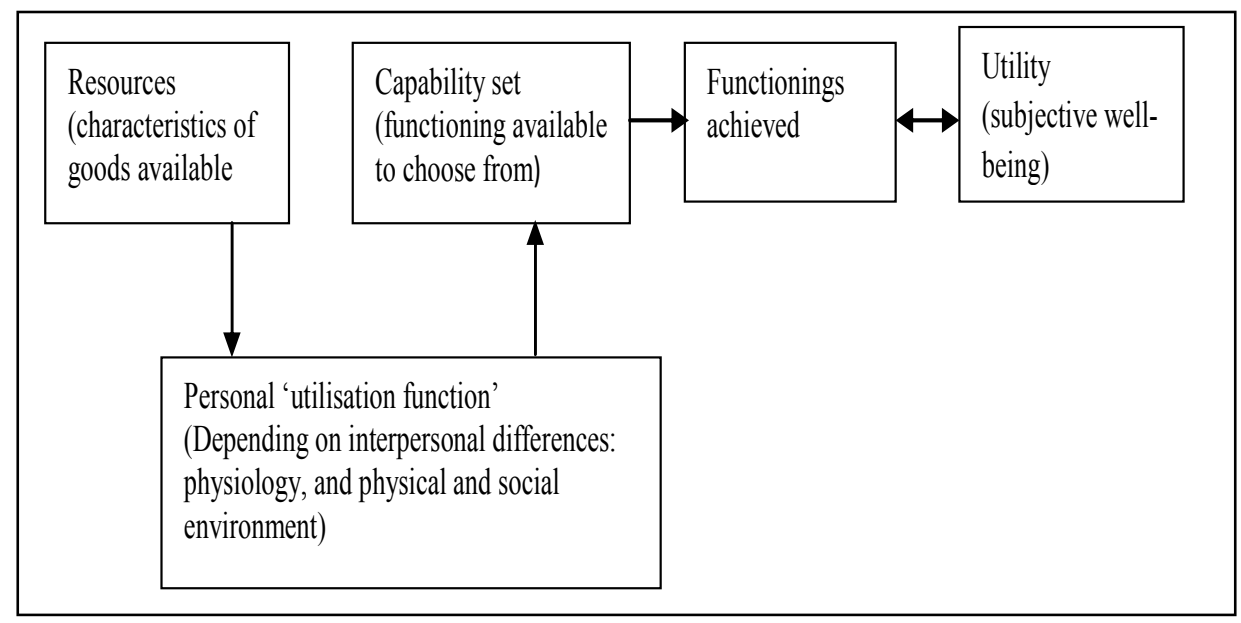

Figure1: Outline of the core relationships in the Capability Approach Source: www.iep.utm.edu/wp-content/media/Sen-chart1.jpg

Thus, a person's capability represents the effective freedom of an individual to choose between different functioning combinations - between different kinds of life - that $\mathrm{s} /$ he has reason to value. This allows analysis to focus on sets of functioning(s) related to particular aspects of life, for example, the capabilities of literacy, health, or political freedom. Consequently, young people who constitute more than 60 percent of the Nigerian population (NDHS, 2013) are invaluable commodities with deployable capabilities (intrinsic values) for national development.

To elaborate on the functional status of young people, I will quote from the work of Obono and Mohammed (2010) on the liminality of adolescent sexual and reproductive behaviour in which the status of young people was thus described:

Adolescence's functional dormancy is not akin to a biological pupal stage, as it were, in human development because, prior to the industrial revolution, the ambiguities currently identified with adolescence were unknown to human society. All roles across the social strata were usually defined quite clearly. The period now known as "adolescence" was not accompanied by the tensions and notions of irresponsibility now associated with it until the demands of industrial society for a period of formal training and apprenticeship cast that cohort into its present liminal mould. pp. 55

This description highlights the point that young people during the preindustrial era were not limited in their functionality. Their capabilities were channelled in ways which do not require any need for formal training and apprenticeship. Thus, formalisation of training and apprenticeship was the 
product of the capitalist industrial society. In other words, the emergence of industrial capitalist society was and still is responsible for a culturally transmuted and socially ambiguous population of young people whose functional status are no longer compatible with industrial capitalism until they acquire certain skills or apprenticeship in a formal institution. Here lies the history of the formation and subsequent expansion of the educational system to become a vehicle for the production of an army that will service the demand of labour within the industrial capitalist society. In the word of Obono and Mohammed (2010) - they represent the "sideline sacrifice for industrial development".

But has the establishment and subsequent proliferation of tertiary educational institutions in Nigeria guaranteed the production of a functional and capable labour force? In other words, how have the educational institutions expanded the capabilities of young people to function within the industrial capitalist Nigerian society? The answer to this question is not far-fetched. The current rate of unemployed young people and the massive army of betweenschool young people whose population expands every year provide a ready answer. Thus, at best, the current tertiary educational system in Nigeria has created an atrocious ambiguity in the capability and functioning of young people.

A NISER (2013) report shows that between 2008 and 2012, nearly 20 percent of young graduates of tertiary institutions have consistently remained unemployment and would often remained unemployed for upward of five years after graduation (NISER, 2013). 


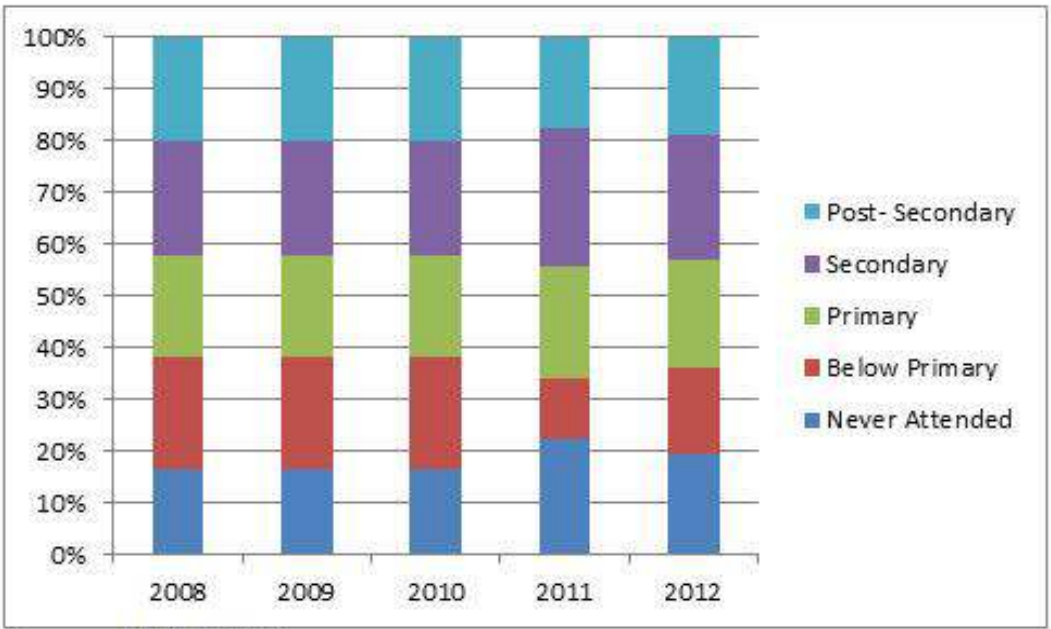

Source: NISER, 2013

Figure 2: Youth unemployment by education

The figure shows that another 20 percent of unemployed young people represent those with secondary education. In sum, about 40 percent of unemployed young people in Nigeria have secondary education and above. The capabilities of this teeming population of young people lie in waste and as Obono and Mohammed (2010: 58) has put it succinctly, "they are travelling without travelling..." "...they are neither here nor there...", and "their "there" is at best notional, never concrete". They represent a population whose potentials and capabilities remain untapped.

A critical look at the disciplinary focus of tertiary educational institutions in Nigeria shows that specialization is very minimal. While there are evidences that few universities specialize in agriculture and technology, the fact remains that these universities are gradually mutating from their core programmes to general programmes in a bid to attract more applicants and thus generate more revenue. The curriculum that guides the programmes of most tertiary institutions in Nigeria is patterned after western colonial educational system. A curriculum which addresses the needs of the local industry would have required federal universities of agriculture, in partnership with universities of science and technology, not only to cultivate improved seedlings through biotechnology, but also to develop a technology for transforming farm produce such as cocoa, palm kernel, cassava, rubber, etc., into other products. 
Table 1: The list and grouping of higher institutions in Nigeria as at 2013

\begin{tabular}{|c|c|c|}
\hline Type & Categories of Higher Institutions & Number \\
\hline \multirow[t]{7}{*}{ Universities } & Federal Universities & 25 \\
\hline & Federal Universities of Agriculture & 3 \\
\hline & Federal Universities of Technology & 6 \\
\hline & State Universities & 30 \\
\hline & State Universities of Technology & 5 \\
\hline & Private Universities & 45 \\
\hline & Other Degree Awarding Institutions in Nigeria & 62 \\
\hline Total & \multicolumn{2}{|l|}{ 管 } \\
\hline \multirow{8}{*}{$\begin{array}{l}\text { Polytechnics } \\
\text { and } \\
\text { Monotechnics }\end{array}$} & Federal Polytechnics & 24 \\
\hline & State Polytechnics & 40 \\
\hline & Polytechnics with NCE Programmes & 7 \\
\hline & Private Polytechnics & 18 \\
\hline & Federal Monotechnics & 22 \\
\hline & State Monotechnics & 17 \\
\hline & Private Monotechnics & 2 \\
\hline & Colleges of Health Sciences & 2 \\
\hline Total & \multicolumn{2}{|l|}{ (2) } \\
\hline IEIs & Innovative Enterprise Institutions (IEIs) & 61 \\
\hline \multirow{5}{*}{$\begin{array}{l}\text { Colleges of } \\
\text { Education }\end{array}$} & Federal Colleges of Education (Regular) & 12 \\
\hline & Federal Colleges of Education (Technical) & 8 \\
\hline & Federal Colleges of Education (Special) & 1 \\
\hline & State Colleges of Education & 46 \\
\hline & Private Colleges of Education & 42 \\
\hline \multirow[t]{2}{*}{ Total } & Total & 109 \\
\hline & Grand Total & 478 \\
\hline
\end{tabular}

With 132 polytechnic and monotechnic institutions, local needs could effectively be addressed if tertiary educational institutions specialise in different sectors of the economy with the aim to interface with stakeholder in other to promote research and development and knowledge translation. In essence, the curriculum of tertiary educational institution is too narrow. The implication is that institutions will not be able to expand both in quality and in quantity and therefore, expand the choices of young people. Resulting from this predicament, Nigeria now has a huge number of young people seeking enrolment and over-bloated force of unemployed young people whose skills and capabilities are at variance with local needs. This therefore underscores the need for innovation in restructuring tertiary educational system and adjusting the curriculum contents to accommodate local industrial needs. 


\section{The Need for Innovation in Curriculum Contents}

Globally, new choices are emerging through advancement in knowledge, information and communication technology. The level of human development at the global level has increased (Adebisi, 2014). At the centre of this change is the expansion of knowledge which has characterised $21^{\text {st }}$ century societies. However, while few Asian countries, categorised as Third World, have advanced beyond that nomenclature, most African countries are looking for a way out (Ajake et al., 2014).

Nigeria, the most populous nation in Black Africa, is not left out. The quest to develop through space technology, economic diversification, reduction in unemployment rates, expanded the productive base of small and medium scale enterprises (SMEs). Vision 20:20:20, as highlighted in the NEEDS document (FRN, 2004), underscores genuine efforts by the Nigerian government to meet up with this global challenge. But the general oversight and undoing of past attempts is poor investment in human capital development, particularly the inability to restructure the educational system to meet up with local needs and demands (Babalola, 2007). Consistently, the annual budgetary allocation to education by the Nigerian government has continued to drop (Shu'ara, 2010). Not only this, the system and policy on education to be adopted have consistently been unstable; from 6-5-4 Universal Primary Education (UPE) of 1976, and to the 6-3-3-4 introduced by Jubril Aminu in 1987, and now to the Universal Basic Education (Ademola et al., 2014). The short of it is that the structure of educational policy is highly fragile, and investment in the educational sector has been very poor over several decades (Ifionu and Nteegah, 2013). The historical nature of the instability in investment in education and its attendant consequences were aptly captured by Akaje et al. (2014: 22) when they observed that the Nigerian educational system:

... viz-a-viz its educational policies shows that with effect from 1960 , emphasis was on the production of high level manpower to fill vacant position that would be created to fill vacancies at the exit of the expatriates after independence in report of 1960 (FBN,1960). The implementation of the Ashby commission was a failure due to its inability to meet its objectives (Akangbou, 1985, Babalola, 2003 and Fubunmi, 2004). The 1981 NPE paid adequate attention to self-employment through the introduction of 6-3-3-4 system of education and the introduction and expansion of vocational and technical education (NPE, 2004). In this regard was the setting up of the National Board for Technical Education (NBTE). However, section 5 of the NPE (2004) dealt with university and higher education policy and was emphatic on science and technology but silent on selfemployment after university education. This can be used to explain the low productivity when compared to economies such as South-Africa, Korea, Japan and USA. 
This submission clearly shows that Nigeria does not have a consistent educational system and policy that interface with local industries, thus, the need to restructure the educational system and adjust the curriculum. Restructuring of the tertiary educational system would take two forms. The first requires the development of programmes that meet the scientific, technological, and industrial needs of the country. In doing this, the productive spheres are to be identified and classified. The establishment of colleges or specialized technical tertiary educational institutions that specialize in various aspects of science and technology would form the institution of learning for these sectors. For example, a college of building technology which has various departments such as roofing, tilling, plumbing, painting, and other departments overseeing other aspects of building technology. This, of course, cannot function adequately without reactivating the technical colleges which will form the foundation of knowledge acquisition for the teeming population of young people. Another area of focus would be that of automobile industry where young people are exposed to different aspects of automobile technology. These colleges will be linked up with relevant ministries, departments and agencies, for instance, the ministry of science and technology to fund research programs that focus on how raw materials could be used for manufacturing purposes. This will create the mid-level skills required for small and medium scale enterprise (SMEs) known globally for driving contemporary advanced economies (Babalola, 2007).

The second would require the development and enrichment of Higher Education curriculum to enable it tackle the challenges highlighted (Ajake et al., 2014). This can be achieved through innovation in contents, integration of practical skill acquisition and practical application of Information and Communication Technology (ICT) in all facets of teaching and learning. Since we now live in a time of a very rapid social and economic transformation, skill acquisition is an indispensable factor in achieving national growth and consolidation of international relations (Drucker, 1994).

\section{Summary and Conclusion}

The current tertiary educational curriculum and the widespread value which places emphasis on certification rather than capability inhibit the functioning of young people in Nigeria. Consequently, a large proportion of young people have acquired skills from Nigerian tertiary educational institutions which are at variance with local needs. In other words, tertiary educational institutions do not provide the opportunity as well as the environment for the functioning of inherent capabilities of young people in Nigeria. In the words of Ajake et al. (2014), the current practice that focuses mainly on intellectual learning results in a curriculum that is not just narrow, but shallow. At best, it will continue to produce a group of young people without relevant skills to effect a progressively sustainable development agenda. By restructuring the tertiary 
educational system and adjusting the curriculum, choices will be created, and opportunities are expanded for the teeming population of in-between school young people in Nigeria. Similarly, unemployment rate will drop gradually and consistently as new channels for job creation would have been created. This will contribute, in a significant way, to the rapid growth and development of the Nigerian nation. Finally, for a sustainable growth and development to be achieved, there must be a synergy of demand and supply between tertiary educational institutions and the various sectors of the Nigerian industrial capitalist society.

\section{References}

Adebisi, T.A. (2014) Higher education and skills development: An overview of Nigerian National Policy on Education (NPE). International Journal of Development and Sustainability. ISSN: 2186-8662 - www.isdsnet.com/ijds 3(12): 2218-2227. ISDS Article ID: IJDS14102401.

Ademola, E.O.; Ogundipe, A.T. and Babatunde, W.T. (2014) Students' Enrolment into Tertiary Institutions in Nigeria: The Influence of the Founder's Reputation -A Case Study. Computing, Information Systems, Development Informatics \& Allied Research Journal. 5(3). September 2014 - www.cisdijournal.net .55

Ajake, U.E.; Oba, A.N.; Ekpo, T.E. (2014) Enriching Higher Education Curriculum to Meet the Challenges of 21 st Century in Nigeria. Journal of Educational and Social Research. Rome-Italy: MCSER Publishing. 4(3).

Ajake, E.U.; Essien, M.I. and Omori, A.E. (2011) Sustainable Development in Higher education: Curre Practice and future development: A case study of university of Calabar. African Higher Education Review (AHER) 4: 87110.

Ajeyalemi, D. (2009) Issues of Quality \& Quantity in Nigeria's teacher education system. Retrieved online at: http://www.deta.up.ac.za/archive2007/presentations/word/THE\%20ISSUES\%20OF\%20. QUALITY\%20Ajeyalemi\%20D.pdf.

(2005) "Challenges of Teacher education for secondary schools' in Nigeria". Paper presented at a two-day National workshop on the country crisis of secondary school education in Nigeria. Confronting old and new challenges.

(2002) "Capacity building in the Science imperative for Teacher Education in Nigeria". An Inaugural Lecture delivered on November 6, 2002, at the University of Lagos. University of Lagos Press.

Akangbou, S.D. (1985) The economics of educational planning in Nigeria. India: Vikas publishing House.

Aluede, O.; Idogho, P.O.; Imonikhe, J.S. (2012) Increasing Access to University Education in Nigeria: Present Challenges and Suggestions for the Future. The African Symposium: An online journal of the African Educational Research Network 3. 12(1). June 2012 The African Symposium (ISSN\# TX 6-342-323). 
Sen, A. (1987) Commodities and Capabilities. New Delhi: Oxford University Press.

Babalola, J.B. (2007) "Reinventing Nigerian Higher Education for Youth Employment in a Competitive Global Economy", Retrieved 31 January, 2013 from www.herp-net.org. (2003) University funding responses and performances under a declining economy in Nigeria. Staff seminar Series Department of Educational management, Ibadan: University of Ibadan.

Drucker, P.F. (1994) The Age of Social Transformation, Atlantic Monthly, 274(53-6): 53-80.

Fakomogbon, M.A. and Adegbija, M.V. (2011) "Higher Education and Current Issues on Skills Development in Nigeria", Journal of Research in Education, 1(1): 195-199.

FRN (2004) National Economic Empowerment and Development Strategy (NEEDS). National Planning Commission, Abuja: Nigeria.

Human Development Report (2013) The Rise of the South: Human Progress in a Diverse World. Explanatory note on 2013 HDR composite indices. ttp://hdr.undp.org/sites/default/files/Country-Profiles/NGA.pdf.

Ifionu, E.P. and Nteegah, A. (2013) Investment in Education and Economic Growth in Nigeria: 1981-2012. West African Journal of Industrial and Academic Research, 9(1), December 2013.

Shu'ara, J. (2010) Higher Education Statistics; Nigeria Experience in Data Collection Federal Ministry of Education, Abuja. Paper presented at the UNESCO Institute of Statistics Workshop on Education Statistics in Anglophone Countries, Windhoek 17-21 October 2010.

Joint Admissions and Matriculation Board (JAMB) Brochure 2013/2014 Unified Tertiary Matriculation Examinations (UTME), Abuja, JAMB.

National Bureau of Statistics (2012) Labour Force Statistics No. 476. Abuja: The NBS Publication. Retrieved from http://www.nigerianstat.gov.ng. (2010) Labour Force Survey March, 2009. ISSN 0794-1954. NO.476 13th May.

National Population Commission (NPC) [Nigeria] and ICF International (2014) Nigeria Demographic and Health Survey 2013.Abuja, Nigeria, and Rockville, Maryland, USA: NPC and ICF International.

Obanyan, F.O.B. (2006) Innovative consideration in curriculum content and delivery methods in Nigerian higher education and management implication, In J.B. Babalola, L. Papoola, A. Onuka, S. Oni, W. Olatokun \& R. Ahgolahor (eds.). Reforming Higher Education in Africa. pp 183197.

Obono, O. and Mohammed, M. (2010) The Liminality of Adolescent Sexual and Reproductive Behaviour in Ibadan, Southern Nigeria. The Nigerian Journal of Sociology and Anthropology. ISSN: 0331-4111. 8: 55-85. 
Odejide, A.; Akanji, B. and Odekunle, K. (2006) Does expansion mean inclusion in Nigerian higher education? Women's Studies International Forum (2006), doi:10.1016/j.wsif.2006.10.006.

Onuka, A.O.U. (2008) Funding the Nigerian University Education: Role of Various Stakeholders In B. Babalola, L. Papoola, A. Onuka, S. Oni, W. Olatokun \& R. Ahgolahor (eds.). Revitalization of African higher Education, pp 149-161.

Report of the Economic Section, United States Embassy in Nigeria (2012) Diplomatic Drive Central Area Abuja, FCT, Nigeria.

Saint, W.; Hartnett, T. and Strasner, E. (2003) Higher Education in Nigeria: A status report. Higher Education Policy, 16: 259-281.

Salmi, J. (2001) Tertiary education in the 21 century: challenges and opportunities. Higher Education Management, 13(2): 105-129.

Shu'ara, J. (2010) Higher Education Statistics Nigeria Experience in Data Collection. Paper presented at the UNESCO Institute of Statistics Workshop on Education Statistics in Anglophone Countries, Windhoek 17-21 October, 2010.

UNICEF, United Nations Population Division and United Nations Statistics Division. http://www.unicef.org/infobycountry/stats_popup10.html.

World Bank (1999) African Development Indicators 1998/99, the World Bank, Washington, D.C. 